UDC 546:544.35:538.95

\title{
THERMODYNAMIC ANALYSIS AND DEFECTION FORMATION IN ALLOYS ON THE BASIS OF LEAD SELENIDE CONTAINING COPPER
}

\author{
A.N. Mamedov ${ }^{1,2}$, N.Ya. Akhmedova ${ }^{2}$, C.M. Asadov ${ }^{1}$, \\ N.B. Babanly ${ }^{3}$, E.I. Mamedov ${ }^{2}$ \\ ${ }^{1}$ Institute of Catalysis and Inorganic Chemistry of the National Academy of Sciences of Azerbaijan \\ H. Javid Ave.,113, AZ 1143, Baku; e-mail: asif.mammadov.47@mail.ru \\ ${ }^{2}$ Azerbaijan Technical University \\ H. Javid Ave. 107, AZ-1073 Baku \\ ${ }^{3}$ Baky State University \\ Z.Khalilov str.33, AZ 1073, Baku
}

Received 04.01.2019

\begin{abstract}
The process of crystallization of the PbSe liquidus surface in the $\mathrm{Cu}-\mathrm{Pb}-\mathrm{Se}$ system was investigated. Equations were obtained to calculate the partial excess energy functions of mixing lead and selenium for $\mathrm{Cu}-\mathrm{Pb}-\mathrm{Se}$ alloys saturated with lead selenide. The obtained analytical dependences $T-x-y$ and $p\left(S_{2}\right)-T-x$ were visualized. It found that when describing the effect of selenium partial pressure on Gibbs partial molar free energy at high pressure, it is necessary to take into account the contribution of the volumetric member. Changes in the energy of defect formation from the electronic chemical potential function in samples based on $\mathrm{PbSe}$ in $\mathrm{Cu}-\mathrm{Pb}-$ $\mathrm{Se}$ were studied. Proceeding from the constructed $\mathrm{Cu}-\mathrm{Pb}-\mathrm{Se}$ phase diagram of the isothermal section, a single phase region was determined based on PbSe and two phase regions between PbSe and copper selenides.
\end{abstract}

Keywords: thermodynamics, phase equilibrium in $\mathrm{Cu}-\mathrm{Pb}-\mathrm{Se}$, defect formation energy, doped samples.

Doi.org/10.32737/2221-8688-2019-1-16-25

\section{INTRODUCTION}

Materials based on lead and copper chalcogenides are of interest for the production of semiconductor, photovoltaic and thermoelectric elements [1-3]. The following compounds are present in the $\mathrm{Pb}-\mathrm{Se}$ and $\mathrm{Cu}-$ $\mathrm{Se}$ systems, respectively: $\mathrm{PbSe}$ and $\mathrm{Cu}_{2} \mathrm{Se}$, $\mathrm{Cu}_{3} \mathrm{Se}_{2}, \mathrm{CuSe}, \mathrm{CuSe}_{2}$ [4,5]. Their use in electronics imposes special requirements on properties and quality of structure of the obtained materials. The above stated is confirmed by advances in the synthesis of materials with controlled properties based on $\mathrm{PbS}$ [6], $\mathrm{PbSe}$ [7] and $\mathrm{Cu}_{2} \mathrm{Se}$ [8].

Dopants are a key factor to control properties of semiconductors under various applications. Impurities, for example, make it possible to control the carrier sign and the density of the charge state. In a semiconductor with an ideal doping impurity, an excess charge is directly related to the concentration of the doping impurity. In $\mathrm{PbSe}$, the should be noted that lead chalcogenides with a replacement metal atom, for example, $\mathrm{Na}$, for the $\mathrm{Pb}$ atom is an ideal p-type dopant, since each $\mathrm{Na}$ atom brings one additional hole. However, the use of PbSe:Na material is limited which is due to the precipitation of the dopant $\mathrm{Na}$ and the formation of the secondary phase of the impurity [9]. This sort of formation and evolution of undesirable secondary phases damage the stability and purity of the $\mathrm{PbSe}: \mathrm{Na}$ material. The phase diagram of multicomponent systems provides important information about design of the material active in solving the problems above. However, experimental phase diagrams of ternary and complex systems at high pressures or involving non-stoichiometric phases are not always available or available without sufficient details in the area of interest. Such being the case, phase diagrams are calculated to provide alternative recommendations and assist in developing new materials [10]. It rock salt structure are of photoelectric [11] and 
thermoelectric materials [12] to be used within the range of $600-900 \mathrm{~K}$ [13] where their zT exceeds 1 for p-type materials [14]. Given this, metallic impurities in $\mathrm{PbSe}$ can exert control over the concentration of hole carriers [12]. This leads to zT close to 1 at $850 \mathrm{~K}$ in PbSe [14]. For $\mathrm{Cu}-\mathrm{Pb}-\mathrm{Se}$ ternary alloys, data on the crystallization surface and thermodynamic characteristics associated with high pressure conditions, as well as characteristics of defect formation based on binary compounds, are difficult to obtain experimentally and are absent for $\mathrm{Cu}-\mathrm{Pb}-\mathrm{Se}$ alloys [15]. In this study, a thermodynamic approximation of the liquidus surface of phase diagram of the $\mathrm{Cu}$ $\mathrm{Pb}$ - Se system at high pressure was performed. The thermodynamics of defects of ideal dopants in a $\mathrm{PbSe}$ semiconductor with a narrow band gap $(\sim 0.3 \mathrm{eV})$ was analyzed.

\section{EXPERIMENTAL PART}

To construct the liquidus surface of the $\mathrm{Cu}-\mathrm{Pb}-\mathrm{Se}$ phase diagram, we studied ternary alloys. The initial compounds $\mathrm{Cu}_{2} \mathrm{Se}$, $\mathrm{CuSe}$ and $\mathrm{PbSe}$ were synthesized by fusing elementary components of high purity in stoichiometric ratios in the evacuated $\sim 10^{-2} \mathrm{~Pa}$ and sealed quartz ampoules. To obtain a stoichiometric $\mathrm{Cu}_{2} \mathrm{Se}$ composition, after quenching, a hardening was performed at 1300 $\mathrm{K}$ in cold water. Following the synthesis, an incongruently melting $\mathrm{CuSe}$ compound was annealed at $600 \mathrm{~K}$ for $500 \mathrm{~h}$. The individuality of the synthesized compounds was controlled by means of differential thermal analysis (DTA) (a device for thermal analysis NETZSCH-404 F1 Pegasus system) and X-ray phase analysis (XRD) (D8 ADVANCE diffractometer Bruker, $\mathrm{CuK}_{\alpha}$-radiation). Alloys of the $\mathrm{Cu}-\mathrm{Pb}-\mathrm{Se}$ system along with $\mathrm{Cu}_{2} \mathrm{Se}-$ $\mathrm{PbSe}, \mathrm{Cu}_{2} \mathrm{Se}-\mathrm{Pb}, \mathrm{Cu}-\mathrm{PbSe}, \mathrm{CuSe}-\mathrm{PbSe}$ sections were prepared by fusing the initial binary compounds and $\mathrm{Cu}(\mathrm{Pb})$ elements in evacuated quartz ampoules using the procedure [16-18].

\section{THEORETICAL PART}

The calculation of the energy of defect formation $\mathrm{Cu}-\mathrm{Pb}-\mathrm{Se}$ was carried out on the basis of the density functional theory (DFT) $[19,20]$ which provides information on the properties of weakly doped semiconductors [21]. The limits of the solubility of the $\mathrm{Cu}$ dopant in the $\mathrm{PbSe}$ phase in the $\mathrm{Cu}-\mathrm{Pb}-\mathrm{Se}$ system were determined using DFT through the calculation of formation energies of internal and external defects consisting of

$$
\Delta E_{d, q}=\left[E_{d, q}-E_{H}\right]+\sum_{\alpha} n_{\alpha}^{d}\left(\mu_{\alpha}^{0}+\Delta \mu_{\alpha}\right)+q\left(E_{\mathrm{V} \mathrm{BM}}+\Delta V_{\mathrm{PA}}+\mu_{\varepsilon}\right)+\Delta E_{I C}
$$

where $E_{d_{x} q}$ and $E_{H}$-the total energy of the DFT of the PbSe sublattice containing the $\mathrm{PbSe}$ sublattice, and the pure $\mathrm{PbSe}$ sublattice, respectively, $n_{\alpha}^{d}$-amount added $\left(n_{\alpha}^{d}=-1\right)$ or removed $\left(n_{\alpha}^{d}=+1\right)$ atoms from the pure sublattice for defect formation, $\mu_{\alpha}^{0}$ is the chemical potential of element $\alpha$ in its standard state, $\Delta \mu \_\alpha$ is the change in chemical potential $\alpha$ corresponding to a specific phase equilibrium between $\mathrm{PbSe}$ and other components in the $\mathrm{Cu}-\mathrm{Pb}-\mathrm{Se}$ system. $\mathrm{E}_{\mathrm{V} \text { вM }}$ is the energy of the maximum of valence band vacancies $\left(\mathrm{V}_{\mathrm{Pb}}, \mathrm{V}_{\mathrm{Se}}\right)$, substitution defects $\left(\mathrm{Se}_{\mathrm{Pb}}, \mathrm{Pb}_{\mathrm{Se}}\right)$ and interstitial defects $\left(\mathrm{Se}_{\mathrm{i}}, \mathrm{Pb}_{\mathrm{i}}\right)$. Defects consisting of $\mathrm{Cu}$ substitution defects on $\mathrm{Pb}$ or $\mathrm{Se}\left(\mathrm{Cu}_{\mathrm{Pb}}, \mathrm{Cu}_{\mathrm{Se}}\right)$, as well as interstitial defects $\mathrm{Cu}\left(\mathrm{Cu}_{\mathrm{i}}\right)$, all in neutral and charged states from -2 to +2 , were taken into account. The equation for calculating the energy of formation of the defect ${ }_{d}$ and the charge ${ }_{q}$ has the form [22]

(VBM) and corresponds to the energy of the highest occupied level. $\Delta V_{\mathrm{PA}}$ is the potential equalization correction factor (PA) used to relevel the energy rates of defects with the energy levels of the host sublattice and is calculated using $\Delta V_{\mathrm{PA}}=\overline{\left(V_{d, q}^{r}-V_{H}^{r}\right)}$ [23], where $\quad V_{d, q}^{r}$ and $V_{H}^{r}-$ spherically-averaged electrostatic potentials of supercomplexes of defects and hosts, respectively, far from the place of defect, in order to avoid any side chemical interactions with it. The correction 
potential equalization coefficient ranges from $+0.08 \mathrm{eV}$ to $-0.13 \mathrm{eV}$ for various charged defects. $\Delta \mathrm{E}_{\mathrm{IC}}$ is the energy term of the image correction of the charge that is added to the energy of defect formation in order to simulate the charge of an isolated defect in a sublattice of limited size under non-degenerate conditions and is calculated using [24]. Owing to the relatively high dielectric constant of $\mathrm{PbSe}$, the value of $\Delta \mathrm{E}_{\mathrm{IC}}$ has a maximum value of $\sim 7 \mathrm{meV}$ at $\mathrm{q} \pm 2$ charges and, thus, has a minimal effect on the value of the formation energy of defects in the calculations. Finally, the value of $\mu_{\mathrm{e}}$ in equation (1) is an electronic chemical potential which is the additional energy of electrons in our system. As for graphs showing changes in the energy of defect formation as a function of electronic chemical potential, the value of $\mu_{\mathrm{e}}$ was set in the range of the VBM energy values and the minimum of the conduction band. The value of $\mu_{\mathrm{e}}$ was calculated as a function of temperature
$\mathrm{T}$ and sets of chemical potentials by solving the charge neutrality condition [9]. DFT calculations of energy of defects and sublattices of host atoms were performed using density perturbation theory [25].Ion-electron interactions were described using selfconsistent wave potential method [26]. Electrons $\mathrm{Pb}: 5 \mathrm{~d}^{10} 6 \mathrm{~s}^{2} 6 \mathrm{p}^{2}$, Se: $4 \mathrm{~s}^{2} 4 \mathrm{p}^{4}$ and $\mathrm{Cu}$ : $3 \mathrm{~d}^{10} 4 \mathrm{~s}^{1}$ taken as valence states in the potentials of self-consistent field. All calculations for the sub-lattices were performed on the selected $5 \times 5 \times 5$ sub-lattice of the primitive cell, which contained 250 atoms. The cutoff energy of the flat wave base was set to $400 \mathrm{eV}$; for electron smearing, a Gaussian spreading width of 0.1 $\mathrm{eV}$ was used [27]. The thermodynamic properties of phases in the $\mathrm{p}-\mathrm{T}-\mathrm{x}$ phase diagram [2,3] of the $\mathrm{Cu}-\mathrm{Pb}-\mathrm{Se}$ system were described within the model of nonmolecular solutions of semiconductors [28, 29] using reference data [30].

\section{RESULTS AND DISCUSSION}

$\mathrm{Cu}_{2} \mathrm{Se}-\mathrm{PbSe}$ is a quasi-binary cross section of the $\mathrm{Cu}-\mathrm{Pb}-\mathrm{Se}$ system. The system is of the eutectic type. The solubility of $\mathrm{Cu}_{2} \mathrm{Se}$ in $\mathrm{PbSe}$ and $\mathrm{PbSe}$ in $\mathrm{Cu}_{2} \mathrm{Se}$ is less than 2 mol. \%. Eutectic composition is 13.5 mol. \% $\mathrm{Pb}, 38 \mathrm{~mol} . \%$ Se to get crystallized at $873 \mathrm{~K}$ (Fig. 1). It was established that the $\mathrm{Cu}-\mathrm{Pb}-$ Se liquidus surface consists of fields corresponding to the primary crystallization of
$\mathrm{Cu}$, the phase based on the high-temperature modification of $\mathrm{Cu}_{2} \mathrm{Se}$, and $\mathrm{PbSe}$-based phase. Fig. 1 shows areas of $\mathrm{Cu}(1), \mathrm{Cu}_{2} \mathrm{Se}(2), \mathrm{PbSe}$ (3), as well as areas of separation of alloys $\left(\mathrm{L}_{1}\right.$ $+\mathrm{L}_{2}$ ), coordinates of eutectic (e), monotectic (m) and peritectic points (p). Of particular practical interest are coordinates of crystallization of $\mathrm{PbSe}$ and $\mathrm{Cu}_{2} \mathrm{Se}$ compounds.

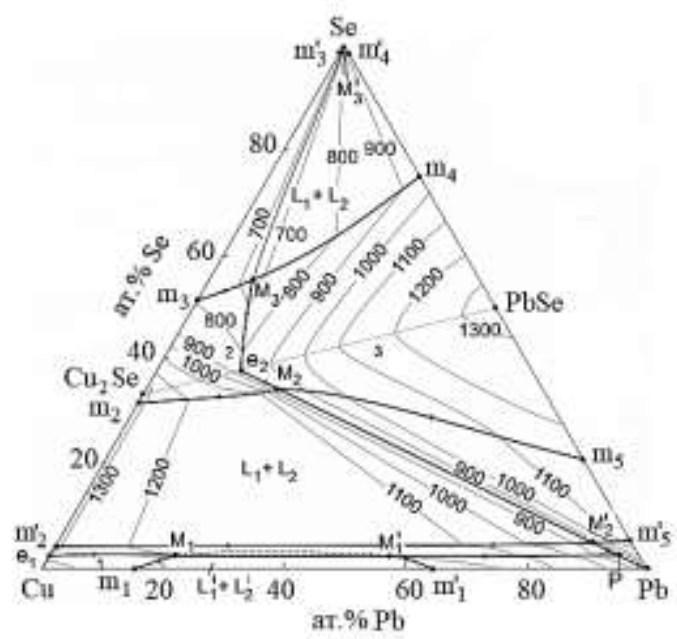

Fig. 1. Projection of the liquidus surface of the $\mathrm{Cu}-\mathrm{Pb}-\mathrm{Se}$ system.

First, we analyze the surface of $\mathrm{PbSe}$ crystallization in the $\mathrm{Cu}-\mathrm{Pb}-\mathrm{Se}$ ternary 
system. PbSe crystallization surface in the $\mathrm{Cu}$ model of non-molecular solutions [28, 29] is $-\mathrm{Pb}-\mathrm{Se}$ system within the framework of the approximated by the equation

$$
\begin{aligned}
\Delta G_{T}^{e x s, L}(\mathrm{PbSe})=\Delta H_{298}^{0} & (\mathrm{PbSe})-\Delta S_{298}^{0}(\mathrm{PbSe})- \\
& -\Delta c_{p, 298} T\left[\ln \left(\frac{T}{298}\right)+\left(\frac{298}{T}\right)\right]-R T \ln x_{\mathrm{pb}} x_{\mathrm{Se}}
\end{aligned}
$$

where $\quad \Delta G_{T}^{e x s_{1} L}=\Delta \bar{G}_{\mathrm{pb}}^{e x s_{1} L}+\Delta \bar{G}_{\mathrm{Se}}^{e x s_{2} L}$; $\Delta \bar{G}_{\mathrm{pb}}^{e x s, L}, \Delta \bar{G}_{\mathrm{Se}}^{e x s, L}$ and $\mathrm{x}_{\mathrm{pb}}, x_{\mathrm{Se}}-$ partial excess free energies and molar fractions of $\mathrm{Pb}$ and $\mathrm{Se}$ components in a liquid solution, saturated with PbSe compound; $\Delta H_{298}^{0}, \Delta S_{298}^{0}-$ enthalpy and entropy of the formation of $\mathrm{PbSe}$ compounds from liquid components; $T$ is the liquidus temperature, $R$ is the universal gas constant. The calculation of $\Delta G_{T}^{e x s, L}$ in the liquidus line of the $\mathrm{PbSe}$ compound in the $\mathrm{Pb}-\mathrm{Se}$ binary system is determined by the expression:

$$
\Delta G_{T}^{e x s, L}=-110693+25.695 T-R T \ln x_{\mathrm{pb}} x_{\mathrm{Se}}
$$

To change the temperature of $\mathrm{PbSe}$ the components in the $\mathrm{Cu}-\mathrm{Pb}-\mathrm{Se}$ ternary crystallization surface on the composition of system with due regard for (3), we obtain

$$
T=\frac{110693+\left(1-x_{\mathrm{Cu}}\right)^{0.35} \Delta G_{\mathrm{PbSe}}^{e x s}\left(x_{\mathrm{Se}}^{L}\right)}{25.693-8.31 \ln x_{\mathrm{Se}}\left(1-x_{\mathrm{Se}}\right)}
$$

Where $\Delta G_{\mathrm{pbSe}}^{e x s}\left(x_{\mathrm{Se}}^{L}\right)$ - the sum of the partial excess molar free energies of lead and selenium is calculated by equation (3) based on the coordinates of the $\mathrm{PbSe}$ liquidus curve. As for the asymmetric dependence (4), the value of the degree 0.35 takes into account changes in the crystallization temperature of $\mathrm{PbSe}$ as a function of the copper concentration in the $\mathrm{Cu}-\mathrm{Pb}-\mathrm{Se}$ melts which is determined on the basis of DTA samples from the $\mathrm{Cu}-$ $\mathrm{PbSe}$ section.

Using dependences of the partial pressure of saturated selenium vapor $[2,3]$ and copper concentration on the temperature on the liquidus surface of $\mathrm{Cu}-\mathrm{Pb}-\mathrm{Se}$ for the $\mathrm{PbSe}-$ $\mathrm{Se}$ (I) and $\mathrm{PbSe}-\mathrm{Pb}$ (II) regions, we obtain (5) and (6) respectively

$$
\begin{aligned}
& \lg p_{\mathrm{Se}_{2}},(P a)=\left[\begin{array}{c}
-1281+5624\left(\frac{1000}{T}\right)-9190\left(\frac{1000}{T}\right)^{2}+ \\
+6648\left(\frac{1000}{T}\right)^{3}-1797\left(\frac{1000}{T}\right)^{4}-10.35 x_{\mathrm{Cu}}^{2}
\end{array}\right] \\
& \lg p_{\mathrm{Se}_{2}},(P a)=\left[\begin{array}{c}
2026-8778\left(\frac{1000}{T}\right)+14247\left(\frac{1000}{T}\right)^{2}- \\
-10259\left(\frac{1000}{T}\right)^{3}+2759\left(\frac{1000}{T}\right)^{4}-8.36 x_{\mathrm{Cu}}^{2}
\end{array}\right]
\end{aligned}
$$

The constructed $\mathrm{PbSe}$ crystallization taking into account equations (5) and (6), is surface in $\mathrm{Cu}-\mathrm{Pb}-\mathrm{Se}$ at high pressure, shown in Fig. 2. 


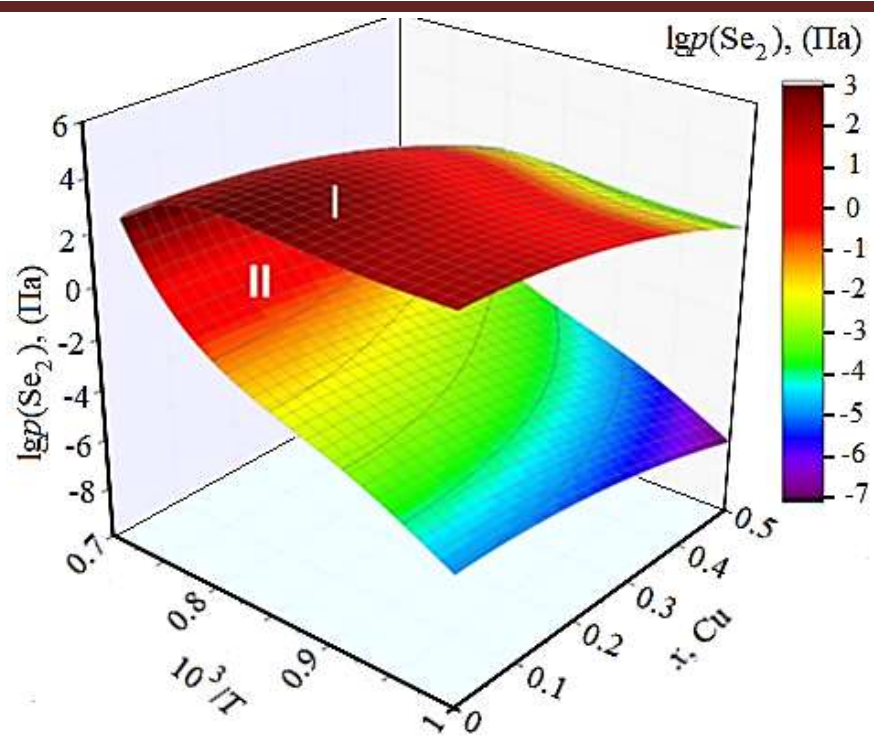

Fig. 2. Projections of the $p-T-x$ phase diagram for the partial pressure of the saturated vapor $\mathrm{Se}_{2}$ over the $\mathrm{PbSe}$ liquidus surface in the $\mathrm{Cu}-\mathrm{Pb}-\mathrm{Se}$ ternary system. $I$ is the $\mathrm{PbSe}-\mathrm{Se}$ region (by equation 5), $I I$ is the $\mathrm{PbSe}-\mathrm{Pb}$ region (by equation 6).

From the $T-x$ phase diagram of $\mathrm{Pb}-\mathrm{Se}[2, \quad$ lead selenide has a narrow homogeneity range. $3]$, it follows that the melting point of $\mathrm{PbSe}$ In considering that the liquid phase $\mathrm{L}$ and the $(1352 \mathrm{~K})$ corresponds to the non- PbSe-based solid solution phaseS are in stoichiometric composition of $\mathrm{PbSe}_{1-\mathrm{x}}$ while equilibrium, we obtain

$$
\mu_{i L}\left(T, p, x_{i L}\right)=\mu_{i S}\left(T, p, x_{i S}\right)
$$

where $\mu_{i L}, \mu_{i s}$-chemical potentials of component $i$ in phases $\mathrm{L}$ and $\mathrm{S}$, respectively. As a standard state, we choose the pure solid or liquid state of component $i$. Then the chemical potential (Gibbs partial molar free energy) of component $i$ in the liquid phase $\mu_{i L}\left(T, p, x_{i L}\right)$ or solid solution $\mu_{i S}\left(T, p, x_{i S}\right)$ is determined by the ratio

$$
\mu_{i L}\left(T, p, x_{i L}\right)=\mu_{i L}^{0}\left(T, p_{0}\right)+R T \ln x_{i L} \gamma_{i L}\left(T, p_{0}, x_{i L}\right)+\int_{p_{0}}^{p} \bar{V}_{i L}\left(T, p, x_{i L}\right) d p
$$

where $(i=1,2)$.

From equation (8), it follows that in terms of high partial pressure of vapors of the components, it is also necessary to take into account the influence of the volume term $\bar{V}_{i L}$ on the Gibbs partial molar free energy of component $i$.
If we consider that $\mathrm{PbSe}$-based surface crystallization in $\mathrm{Cu}-\mathrm{Pb}-\mathrm{Se}$ is characterized by asymmetric appearance, the excess molar volume is determined by the Hillert method, as follows

$$
\begin{aligned}
& V_{m}^{E}=\frac{x_{2}}{1-x_{1}} V_{12}^{E}\left(x_{1}, 1-x_{1}\right)+\frac{x_{g}}{1-x_{1}} V_{13}^{E}\left(x_{1}, 1-x_{1}\right)+\frac{x_{2} x_{g}}{\omega_{28} \omega_{\mathrm{gz}}} V_{23}^{E}\left(\omega_{23}, \omega_{32}\right) \\
& \omega_{23}=\frac{1+x_{2}-x_{g}}{2} ; \omega_{32}=\frac{1+x_{\mathrm{g}}-x_{2}}{2} ; \omega_{23}+\omega_{32}=1
\end{aligned}
$$

where $V_{12}^{E}, \quad V_{13}^{E}$ and $V_{23}^{E}$ are excess molar $V_{m}^{E}$ is excess molar volume for the ternary volumes for three components of the system, system.

Since 


$$
\begin{gathered}
\bar{V}_{i}^{E}=V_{m}^{E}+\frac{\partial V_{m}^{E}}{\partial x_{i}}-\sum_{j=1}^{3} x_{j} \frac{\partial V_{m}^{E}}{\partial x_{j}},(i=1,2,3) \\
\bar{V}_{i}=V_{i}^{0}+\bar{V}_{i}^{E}(i=1,2,3),
\end{gathered}
$$

then the partial molar volume $\bar{V}_{i}\left(T, p_{0}, x_{i}\right)$ for component $i$ on the surface of crystallization in the $\mathrm{Cu}-\mathrm{Pb}-\mathrm{Se}$ system is determined by the values of $V_{i j}^{E}$ for three components $(i=1$ (PbSe), 2( $\left.\left.\mathrm{Cu}_{2} \mathrm{Se}\right), 3(\mathrm{Cu})\right)$.
Finally, at high pressure, when adjusted for the activity coefficient $\gamma_{i}$ of a component, the equation of phase equilibrium at the liquid / $\mathrm{PbSe}\left(\mathrm{S}_{2}\right)$ - based solid solution interface is determined by the following expression

$$
\frac{x_{i, L} \gamma_{i, L}\left(T, p_{0}, x_{i, L}\right)}{x_{i, S_{2}} \gamma_{i, S_{2}}\left(T, p_{0}, x_{i, S_{2}}\right)}=\exp \left(-\frac{\mu_{i, L}^{0}-\mu_{i, S_{2}}^{0}}{R T}\right) \times \exp \left\{\frac{1}{R T} \int_{p_{0}}^{p}\left[\bar{V}_{i, S_{2}}\left(T, p, x_{i, S_{2}}\right)-\bar{V}_{i, L}\left(T, p, x_{i, L}\right)\right] \mathrm{d} p\right\}
$$

Below, we consider the results of calculating the energy of defect formation in $\mathrm{Cu}-\mathrm{Pb}-\mathrm{Se}$. It has been established that the energy of formation of $\mathrm{Cu}_{\mathrm{pb}}^{0}$ defects is negative $(-0.152 \mathrm{eV})$ in three of four areas of three-phase equilibria: $\mathrm{PbSe}-\mathrm{Cu}_{2} \mathrm{Se}-\mathrm{CuSe}$, $\mathrm{PbSe}-\mathrm{CuSe}-\mathrm{CuSe}_{2}$ and $\mathrm{Se}-\mathrm{PbSe}-\mathrm{CuSe}_{2}$. The calculated negative energies of formation of neutral defects, which are independent on $\mu_{\mathrm{e}}$, indicate a zero doping efficiency and do not represent the supposed defect.

Fig. 3 shows the typical dependence of the energy of defect formation with the lowest energies of intrinsic and unrealistic defects in $\mathrm{PbSe}$ as functions of the Fermi level in the $\mathrm{Pb}$ $-\mathrm{PbSe}-\mathrm{Cu}$ equilibrium regions of the $\mathrm{Cu}-$ $\mathrm{Pb}-\mathrm{Se}$ phase diagram. Solid lines indicate defects included in the calculation of the $\mathrm{Cu}-$ $\mathrm{Pb}-\mathrm{Se}$ phase diagram, while dashed lines indicate unrealistic defects. Considering this, when calculating phase diagrams and doping efficiency in line with the experiment, it is necessary to use only the expected charge states for each defect.

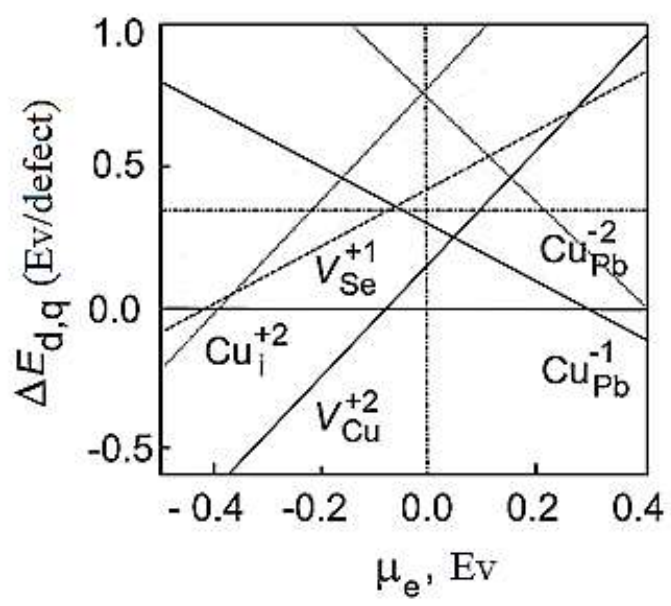

Fig.3. Energy of formation of intrinsic defects $\Delta E_{d_{n} q}$ and unrealistic defects in PbSe depending on the Fermi level, $\mu_{\mathrm{e}}$ (relative to the energy of the maximum of the valence band-VBM) in the three-phase equilibrium region $\mathrm{Pb}-\mathrm{PbSe}-\mathrm{Cu}$ phase diagram $\mathrm{Cu}-\mathrm{Pb}-\mathrm{Se}$. Solid lines indicate defects included in the calculation of the $\mathrm{Cu}-\mathrm{Pb}-\mathrm{Se}$ phase diagram, while dashed lines indicate unrealistic defects. 
admixture of $\mathrm{Cu}$ p-type show that defects with unexpected charge states lead to low energy of defect formation, which do not agree with the experimentally observed $\mathrm{PbSe}$ doping efficiency [11]. This can be traced to the charge delocalization, which changes the charge state of the calculated defect.
Excluding unrealistic defects, in particular, marked with dotted lines in Fig. 3, an isothermal section was constructed characterizing the boundaries of the $\mathrm{PbSe}$ based solid phase at $573 \mathrm{~K}$ on the $\mathrm{Cu}-\mathrm{Pb}-\mathrm{Se}$ diagram(Fig.4).

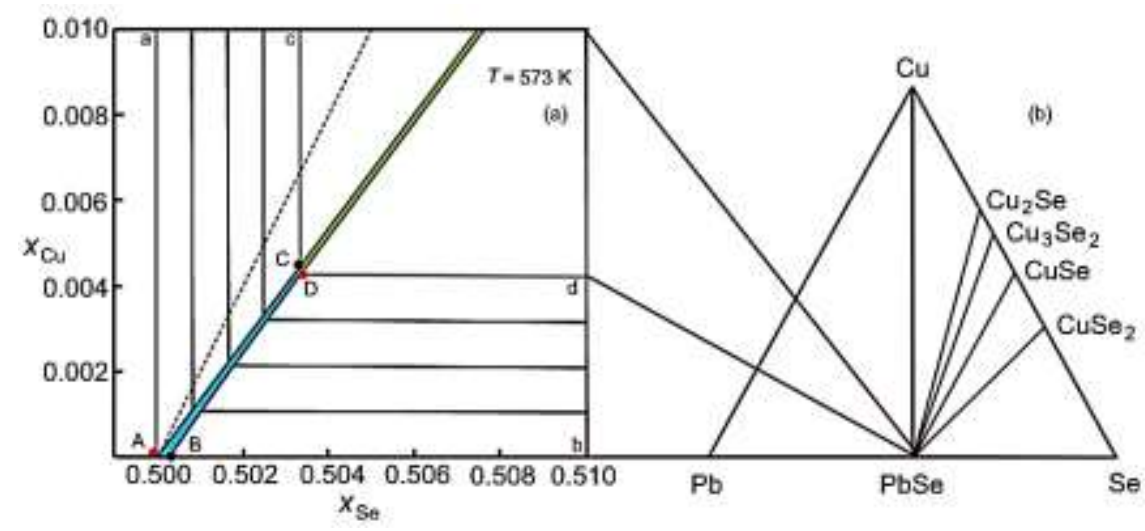

Fig. 4. An isothermal section of the $\mathrm{Cu}-\mathrm{Pb}-\mathrm{Se}$ phase diagram, built at $573 \mathrm{~K}$, shows $\mathrm{PbSe}-$ based single-phase region, as well as connection lines representing two-phase regions between $\mathrm{PbSe}$ and other binary $\mathrm{Cu}-\mathrm{Se}$ compounds which are shown in the full isothermal section (b).

In Fig. 4a, the dotted line represents the path between $\mathrm{PbSe}$ and $\mathrm{Cu}$ for a one-to-one substitution of $\mathrm{Pb}$ with $\mathrm{Cu}$, that is $\mathrm{Pb}_{1-\mathrm{x}} \mathrm{Cu}_{\mathrm{x}} \mathrm{Se}$. Point $\mathrm{B}$ denotes the coordinate of the maximum solubility of $\mathrm{Cu}$ in the three-phase $\mathrm{Pb}-\mathrm{PbSe}-\mathrm{Cu}$ region where it is admitted that the sample demonstrates n-type conductivity. Point $\mathrm{D}$ indicates the solubility coordinate of $\mathrm{Cu}$ in the three-phase $\mathrm{Pb}-\mathrm{PbSe}$ $-\mathrm{Cu}$ region where it is obvious that the sample exhibits p-type conductivity.

The isothermal section of the $\mathrm{Cu}-\mathrm{Pb}-$ Se phase diagram, calculated at $T=573 \mathrm{~K}$, also shows $\mathrm{PbSe}$-based single-phase region in $\mathrm{A}-\mathrm{B}-\mathrm{C}-\mathrm{D}$ region (Fig. 4a). Straight lines in the $\mathrm{A}-\mathrm{a}-\mathrm{c}-\mathrm{B}$ and $\mathrm{B}-\mathrm{D}-\mathrm{d}-\mathrm{b}$ regions are two-phase regions between $\mathrm{PbSe}$ and other $\mathrm{Cu}-\mathrm{Se}$ compounds which are shown in the full isothermal region (b). Thus, equations for calculating the partial excess energy functions of the mixing of lead and selenium for $\mathrm{Cu}-\mathrm{Pb}$ - Se alloys saturated with lead selenide were obtained. Taking into account the constructed surface of crystallization of the components in the $\mathrm{Cu}-\mathrm{Pb}-\mathrm{Se}$ system and the obtained $T-\mathrm{x}$ $-\mathrm{y}$ and $\mathrm{p}\left(\mathrm{Se}_{2}\right)-T-\mathrm{x}$ dependences, the visualization and thermodynamic analysis of these dependences were performed. In describing the effect of pressure on the Gibbs partial molar free energy and phase equilibrium at high pressures of the $\mathrm{Cu}-\mathrm{Pb}-$ Se system, it is necessary to take into account the asymmetric appearance of the volume term. The dependence of the formation energy of intrinsic and unrealistic defects in $\mathrm{PbSe}$-based samples as a function of the Fermi level in $\mathrm{Cu}-\mathrm{Pb}-\mathrm{Se}$ was constructed. The constructed isothermal section of the $\mathrm{Cu}-\mathrm{Pb}$ - Se phase diagram enables to determine, PbSe-based single-phase region and two-phase regions between $\mathrm{PbSe}$ and other $\mathrm{Cu}-\mathrm{Se}$ compounds. In particular, in case of one-toone substitution of $\mathrm{Pb}$ for $\mathrm{Cu}$, the points of maximum solubility of $\mathrm{Cu}$ in the three-phase $\mathrm{Pb}-\mathrm{PbSe}-\mathrm{Cu}$ region where the types of conductivity of the samples were determined. 


\section{Acknowledgements}

This work was carried out with the financial support of Science Development Foundation under the President of the Republic of Azerbaijan. Grant No EIF / MGM / Elm- Tehsil -1 - 2016 -1 (26)-71/05/4 and Grant No EIF-BGM-3-BRFTF-2+/2017-15/05/1-M-13).

\section{REFERENCES}

1. Compounds and Alloys Under High Pressure: A Handbook. / E.Yu Tonkov. CRC Press, Technology \& Engineering. 1998. $584 \mathrm{p}$

2. Abrikosov N.Kh., Bankina V.F., Poretskaya L.V. et al. Semiconducting IIVI, IV-VI, and V-VI Compounds. Springer US. 1969. $260 \mathrm{p}$.

3. Abrikosov N.H., Shelimova L.E. Poluprovodnikovye materialy na osnove soedinenij $A^{I V} V^{V I}$. [Semiconductor materials based on $\mathrm{A}^{\mathrm{IV}} \mathrm{V}^{\mathrm{VI}}$ compounds]. Moscow: Nauka, 1975. 195 p. (In Russian).

4. Ravich Yu.R., Efimova B.A. Smirnov I.A. Metody issledovaniya poluprovodnikov $v$ primenenii khal'kogenidam svinca PbTe, $P b S e, P b S$. [Methods for the study of semiconductors as applied to lead alcogenides $\mathrm{PbTe}, \mathrm{PbSe}, \mathrm{PbS}]$. Moscow: Nauka, 1968. 384 p. (In Russian).

5. Zemskov B.S., Lazarev V.B. Tverdye rastvory $v$ poluprovodnikovyh sistemah. [Solid solutions in semiconductor systems. Handbook]. M.: Nauka, 1978. 198 s. (In Russian).

6. Tulenin S.S., Novotorkina D.A., Rogovoy M.S., Karpov K.A., Pozdin A.V., Maskaeva L.N., Markov V.F. Thermodynamic Analysis and Kinetics of Etching of Thin PbS Films in Hydrochloric Acid Solutions. Zhurnal Prikladnoi Khimii - Russian Journal of Applied Chemistry. 2018, vol. 91, no. 3, pp. 360-367.

7. Zimin S.P., Gorlachev E.S. Nanostrukturirovannye hal'kogenidov svinca. [Nanostructured lead chalcogenides]. Yarosl. State university. Yaroslavl': YArGU, 2011. 232 p. (In Russian).

8. Jin Y., Han M.-K., Kim S.-J. Na-Doping Effects on Thermoelectric Properties of
$\mathrm{Cu}_{2-\mathrm{x}}$ Se Nanoplates. Appl. Sci. 2018, vol. 8, pp. 12; DOI:10.3390/app8010012.

9. Doak J.W., Michel K.J., Wolverton C. Determining dilute-limit solvus boundaries in multi-component systems using defect energetics: $\mathrm{Na}$ in PbTe and $\mathrm{PbS}$. Journal of Materials Chemistry $C$. 2015, vol. 3 (40), pp. 10630-10649.

10. Greenberg J., Thermodynamic Basis of Crystal Growth $p-T-x$ Phase Equilibrium and Non-Stoichiometry. Springer-Verlag Berlin Heidelberg, 2002. 225 p.

11. Gamarts A.E., Yu. M. Spivak, Moshnikov V.A. Determination of the Charge Carrier Concentration in Lead Selenide Polycrystalline Layers Using Reflectance Spectra. Semiconductors, 2005, vol. 39(6), pp. 636-637. DOI: $10.1134 / 1.1944851$.

12. Pei Yanzhong, Shi Xiaoya, Lalonde Aaro n, Wang Heng, Chen Lidong, G. Jeffrey Snyder. Convergence of electronic bands for high performance bulk thermoelectrics. Nature. 2011, vol. 473, no. 7345 , pp. 66-69.

DOI: $10.1038 /$ nature09996.

13. Wang H., Pei Y., Lalonde A.D., Snyder G.J. Heavily doped p-type PbSe with high thermoelectric performance: An alternative for PbTe.Advanced Materials, 2011, vol. 23(11), pp. 13661370. DOI: 10.1002/adma.201004200.

14. Wang H., Cao X., Takagiwa Y. et al. Higher mobility in bulk semiconductors by separating the dopants from the chargeconducting band - a case study of thermoelectric PbSe. Mater. Horiz. 2015, vol. 2, pp. 323-329.

DOI: $10.1039 / \mathrm{c} 5 \mathrm{mh} 00021 \mathrm{a}$.

15. Mamedov A.N., Asadov C.M., Ahmedova N.YA., Babanly N.B., Mamedov EH.I. In the collection "Solid state chemistry 
and functional materials. 2018. Part 3, p. 262.

16. Mustafaeva S.N., Kerimova E.M., Gasanov N.Z., Asadov M.M. Dielectric and optical properties of $\mathrm{TlGa}_{1-\mathrm{x}} \mathrm{Er}_{\mathrm{x}} \mathrm{S}_{2}$ $(\mathrm{x}=0,0.001,0.005,0.01)$ single crystals. Inorganic Materials. 2013, vol. 49, no. 12, pp.

$1175-1179$

DOI: $10.7868 / \mathrm{S} 0002337 \mathrm{X} 13120129$

17. Mustafaeva S.N., Jabbarov A.I., Kerimova E.M., Asadov M.M. Electrical conductivity and thermoelectric power of (TIInSe2)0.2(TlGaTe2)0.8 crystals Inorganic Materials. 2015, vol. 51, no. 3, pp.220-224.

DOI: $10.7868 / \mathrm{S} 0002337 \mathrm{X} 15030112$

18. Asadov M.M., Mamedov A.N., Mustafaeva S.N., Aljanov M.A., Kerimova E.M., Nadjafzade M.D. Dielectric properties and heat capacity of (TlInSe2)1-x(TlGaTe2)x solid solutions. Inorganic Materials. 2015, vol. 51, no. 8, pp.772-778.

DOI: $10.7868 / \mathrm{S} 0002337 \mathrm{X} 15080059$

19. Hohenberg P. and Kohn W. Inhomogeneous Electron Gas. Physical Review B. 1964,vol. 136, pp. 864-871. DOI:10.1103/PhysRev.136.B864.

20. Kohn W., Sham L.J. Self-consistent equations including exchange and correlation effects. Phys. Rev., 1965, vol. 140, A1133-A1138.

21. Julien Vidal, Stephan Lany, Mayeul d'Avezac, Alex Zunger, Andriy Zakutayev, Jason Francis, and Janet Tate. Band-structure, optical properties, and defect physics of the photovoltaic semiconductor SnS. Appl. Phys. Lett. 2012, vol. 100, 032104-032107. DOI: $10.1063 / 1.3675880$

22. Zhang S.B., Northrup J.E. Chemical potential dependence of defect formation energies. Phys. Rev. Lett., 1991, vol. 67, pp. 2339-2342.

23. Lany S., Zunger A. Comparison of Source Apportionment and Sensitivity. Model. Simul. Mater. Sci., 2009, vol. 17, 084002$1-14$.

24. Makov G., Payne M. Periodic boundary conditions in ab initio calculations. Phys. Rev., 1995, B 51, pp. 4014-4022. DOI:10.1103/PhysRevB.51.4014

25. Gajdos M., Hummer K., Kresse G., Furthmüller J., Bechstedt F. Linear optical properties in the projector-augmented wave. Phys. Rev., 2006, B 73, 045112-19.

26. Bengone O., Alouani M., Blochl P. et al. Implementation of the projector augmented-wave. Phys. Rev., 2000, B 62, pp. 16392-16401.

27. Monkhorst H.J., Pack J.D. Special points for Brillouin-zone integrations. Phys. Rev., 1976, B 13, pp. 5188-5192.

28. Asadov S.M., Mustafaeva S.N., Mammadov A.N. Thermodynamic assessment of phase diagram and concentration-temperature dependences of properties of solid solutions of the $\mathrm{GaS}$ GaSe system. J. Therm. Anal. Calorimet. 2018, vol. 131, no. 438. DOI: 10.1007/s10973-018-6967-7

29. Asadov S.M., Mamedov A.N., Kulieva S.A. Composition- and temperaturedependent thermodynamic properties of the $\mathrm{Cd}, \mathrm{Ge} \| \mathrm{Se}$, Te system, containing CdSe1-xTex solid solutions. Inorganic Materials. 2016, vol. 52, no. 9, pp. 876885. DOI: $10.7868 / \mathrm{S} 0002337 \mathrm{X} 16090013$

30. Glushko V.P. Termicheskie konstanty veshchestv. Baza dannyh. URL: http://www.chem.msu.su/cgibin/tkv.pl?show=welcome.html.

\title{
ТЕРМОДИНАМИЧЕСКИЙ АНАЛИЗ И ДЕФЕКТООБРАЗОВАНИЕ В СПЛАВАХ НА ОСНОВЕ СЕЛЕНИДА СВИНЦА, СОДЕРЖАЩИХ МЕДЬ
}

\author{
А.Н. Мамедов ${ }^{1,2}$, Н.Я. Ахмедова ${ }^{2}$, С.М. Асадов ${ }^{1}$, \\ Н.Б. Бабанльз ${ }^{3}$, Э.И. Мамедов
}


Наџиональной АН Азербайджана,

AZ 1143 Баку, пр.Г. Джавида,113; e-mail: asif.mammadov.47@mail.ru

${ }^{2}$ Азербайджанский Технический Университет

AZ 1073 Баку, пр.Г. Джавида,107; e-mail: aztu@aztu.org

${ }^{3}$ Бакинский Государственный Университет

AZ 1073 Баку, ул. 3. Халилова 33: e-mail: info@bsu.az

Исследован процесс кристаллизации поверхности ликвидуса $\mathrm{PbSe}$ в системе $\mathrm{Cu}-\mathrm{Pb}-\mathrm{Se}$. Получень уравнения для расчета парииальных избыточных функций энергии смешения свинца и селена для сплавов $\mathrm{Cu}-\mathrm{Pb}-\mathrm{Se}$, насыщенных селенидом свинща. Проведена визуализачия полученных аналитических зависимостей $T-x-y$ и $p\left(S_{2}\right)-T-x$. Показано, что в описании влияния парииального давления селена на парииальную молярную свободную энергию Гиббса при высоком давлении необходимо учесть вклад объемного члена. Изучено изменение энергии образования дефектов от функиии электронного химического потенциала в образиах на основе $\mathrm{PbSe}$ в $\mathrm{Cu}-\mathrm{Pb}-\mathrm{Se}$. $\mathrm{Ha}$ основе построенного изотермического разреза фазовой диаграммы $\mathrm{Cu}-\mathrm{Pb}-\mathrm{Se}$ определены однофазная область на основе PbSe и двухфазные области между PbSe и селенидами меди.

Ключевые слова: термодинамика, фазовые равновесия в $\mathrm{Cu}-\mathrm{Pb}-\mathrm{Se}$, энергия образования дефектов, легированные образиы.

\title{
TORKIBINDO MIS OLAN QURĞUSUUN SELENID OSASLI XəLITOLORIN TERMODINAMIKI ANALIZI VO ONLARDA DEFEKT OMӘLӘGӘLMӘ
}

\author{
A.N. Mommadov ${ }^{1,2}$, N.Y. Ohmədova ${ }^{2}$, S.M. Osadov ${ }^{1}$, \\ N.B. Babanli ${ }^{3}$, E. I. Mommodov ${ }^{2}$ \\ ${ }^{1}$ AMEA akademik M.Nağıyev adına Kataliz vo Qeyri-üzvi Kimya İnstitutu \\ AZ 1143 Bakl, H.Cavid pr.113; e-mail: asif.mammadov.47@mail.ru \\ ${ }^{2}$ Azarbaycan Texniki Universiteti \\ AZ 1073 Bakı, H.Cavid pr.107; e-mail: aztu@aztu.org \\ ${ }^{3}$ Bakı Dövlat Universiteti; \\ AZ 1073 Bakl, Z.Xalilov küç.33; e-mail: info@bsu.az
}

$\mathrm{Cu}-\mathrm{Pb}$-Se sisteminda PbSe-in likvidus sathi üzra kristallaşma prosesi tadqiq edilmişdir. $\mathrm{Cu}-\mathrm{Pb}$-Se sisteminin qurğuşun sulfidla doymuş xəlitalarinda qurğuşun va selenin parsial izafi sarbast enerjisini hesablamaq ü̧̈ün tanliklar çıxarılmış, $T-x-y$ va $p\left(S_{2}\right)-T-x$ asılllıqlarının analitik ifadalarinin $3 D$ görüntülari alınmişdır. Müayyan edilmişdir ki, selenin parsial tazyiqinin Gibbs sarbast enerjisina tasirini müəyyən etmək üçun bərk fazanın hacm dayişməsinin payını nəzara almaq lazımdır. $\mathrm{Cu}$-Pb-Se sistemində PbSe asaslı xalita nümunalarinda defektlarin amalagalma enerjisinin elektron potensialından asılıliq funksiyası öyranilmişdir. $\mathrm{Cu}$-Pb-Se sisteminin faza diaqramının izotermik kasiyində PbSe-in homogenlik sahasi va onun mis sulfidlari ila amala gatirdiyi iki fazalı sahalar tayin edilmişdir.

Açar sözlor: termodinamika, faza tarzlığl, $\mathrm{Cu}-\mathrm{Pb}$-Se sistemi, parsial tazyiq, defekt amala galməsi 